\title{
O processo de avaliação dos artigos e a sua contribuição para o avanço da área
}

A publicação do último número de um determinado volume, além de marcar o encerramento de um ciclo, proporciona a todos os envolvidos nesta difícil tarefa de gerir um periódico brasileiro um sentimento gratificante de realização. No entanto, representa também um momento propício para reflexões e ponderações.

Uma importante reflexão, não somente para a equipe responsável pela publicação da RBEFE, mas também para toda a comunidade de pesquisadores, refere-se ao processo de avaliação dos artigos e a sua contribuição para o avanço da área de conhecimento.

Oportuno destacar, inicialmente, que os editores da RBEFE, assim como ocorre em outros periódicos científicos brasileiros, dão suas contribuiçōes de forma absolutamente voluntária, executando tarefas específicas que exigem grande dispêndio de tempo e energia, movidos e motivados por um único objetivo: a melhoria qualitativa da Revista e a sua consequente contribuição para o avanço do conhecimento.

Esse trabalho árduo, quase "invisível" é também, muitas vezes, ingrato. Naturalmente, o grande prazer do editor-chefe e dos editores de seção é comunicar ao(s) autor(es) o aceite do artigo submetido para a Revista. Porém, a comunicação de uma não aceitação é sempre penosa e desagradável. Equivocam-se aqueles que pensam o contrário. Definitivamente, o editor não tem nenhuma satisfação em comunicar a não aceitação de um artigo.

O importante é o entendimento de que entre a submissão de um artigo e a comunicação do resultado, existe um processo complexo de avaliação envolvendo o(s) autor(es), os revisores, os editores de seção e o editor-chefe. Ressalte-se a atuação fundamental dos revisores nesse processo. $\mathrm{O}$ seu papel é o de diagnosticar o potencial de publicação do artigo pelo mérito científico que encerra, ou mediante suas sugestóes e comentários, possibilitar a sua melhoria qualificando-o para a publicação.
Por sua vez, cabe ao editor de seção mediar essa comunicação, participando desse diálogo entre os revisores e o(s) autor (es), tendo como interesse maior a efetivação da publicação com um material de qualidade compatível com as exigências da Revista.

Vale lembrar que somos avaliados pelos pares, avaliamos o trabalho dos pares, aceitamos ou não o trabalho de nossos pares, enfim somos "aceitos" ou "não aceitos" por meio de julgamentos feitos pela aplicação de critérios construídos pela nossa própria comunidade.

Diante deste cenário, é fundamental que nesse encerramento de ciclo façamos uma reflexão de todo esse processo de avaliação, e enfatizar a importância e a necessidade de termos uma comunidade de pares com pleno conhecimento do complexo processo que envolve a publicação de artigos, mas, sobretudo, comprometida com a qualidade da Revista e com o avanço do conhecimento na área. Esse comprometimento implica saber lidar com a não aceitação de artigo, da mesma forma que se lida com a aceitação. Ambas implicam possibilidades ímpares de dialogar trocando ideias, conhecimentos, métodos e tecnologias. A possibilidade de diálogo com os pares para melhorar o artigo ou mesmo para discutir as questôes inerentes ao trabalho de pesquisa, é a essência de todo este processo.

Num momento em que se discute a valorização dos periódicos brasileiros, a sua "internacionalização" com todos os seus desafios e possíveis consequências, ainda há muito espaço para se evoluir nesse contexto da relação dual "autor-revisor", para melhor compreender, aceitar e valorizar os seus respectivos trabalhos. Certamente, a reflexão e discussão sobre a valorização dos periódicos brasileiros deve incluir esta questão-chave que, por sua vez, constitui um ótimo indicador de amadurecimento acadêmicocientífico da área.

Prof. Dr. Alexandre Moreira 